\title{
Seasonal changes in quality of wastewater from fruit and vegetable industry
}

\author{
Monika Puchlik ${ }^{1, *}$, and Katarzyna Ignatowicz ${ }^{1}$ \\ ${ }^{1}$ Bialystok Technical University, Faculty of Civil and Environmental Engineering, Department \\ of Technology in Engineering and Environmental Protection, ul. Wiejska 45E, 15-351, Poland
}

\begin{abstract}
The paper aimed at evaluating the seasonal changes in quality of wastewater from facilities producing fruit and vegetable juices, processed and frozen products, and vegetable concentrates. The study revealed that wastewater from fruit and vegetable industry contain large amounts of organic substances expressed as $\mathrm{BOD}_{5}$ (minimum - $500 \mathrm{mgO}_{2} / \mathrm{dm}^{3}$, maximum - $6100 \mathrm{mgO} / \mathrm{dm}^{3}$ ) and COD (minimum $-806 \mathrm{mg} \mathrm{O} / 2 \mathrm{dm}^{3}$, maximum $-7732 \mathrm{mg} \mathrm{O} / \mathrm{dm}^{3}$ ), while is deficient in nitrogen and phosphorus. Considerable seasonal oscillations in sewage load disposed by industry to sewerage, were observed. An increase of $50 \%-60 \%$ wastewater concentrations was found between June and October in 2013-2016 as compared to the remaining months.
\end{abstract}

\section{Introduction}

High-quality water becomes or will become a rare product in many branches. Food production and processing require large amounts of water of different qualities. The water re-use during food production and processing is common practice with probable increase in near future $[1,2]$. Facilities of the food industry having the specificity of particular branch can be a source of many threats for all elements of natural environment - soil, water, air, plants, animals, and human. The foodstuff industry is a division involved in acquiring and processing of natural resources and is one of the links of food economy composed of many elements that are closely associated one to another [3]. The food industry wastewater, like household sewage, is characterized by organic substances expressed as COD and $\mathrm{BOD}_{5}[4$, 5]. Organic compounds contained, however, are decomposed to a lesser extent. They are mainly natural biologically-decomposable high-molecular proteins, carbohydrates, and fats, along with depending on raw material, inorganic salts, admixtures from the soil, as well as disinfection agents. Quantity of wastewater oscillated within very broad limits in reference to the unit amounts of raw material processed of a final product. The wastewater disposal is often uneven and is characterized by sinusoidal shape. In some facilities, it can be reduced

* Corresponding author: m.puchlik@.pb.edu.pl 
to particular seasons (seasonal work, campaign operation). There are about 2400 facilities in Poland; over $90 \%$ are small, while $6 \%$ are large facilities of all processing plants registered in REGON [6]. The processed 1015-1020 thousand tons of fruits and 1070 thousand tons of vegetables in 2013-2014 [7]. The largest amount of processed products in Poland are concentrated juices, frozen products, jams, and puree, fruit and vegetable processing industry is very common, whereas the identification of the food industry facilities interaction to the environment is extremely difficult. It results, among others, from this branch structure in Poland that is characterized by great degree of fragmentation. Therefore, the activities upon the determination of seasonal changes in quality of wastewater from fruit and vegetable industry, were undertaken based on the environment protection issues. It should consist in disposal of wastewater with contaminants loads permissible from a point of view of self-clearing ability of the environment maintenance $[8,9]$.

\section{Characteristics of raw wastewater from fruit and vegetable industry}

Fruit and vegetable processing is characterized by seasonal activity that falls mainly between June and October [10]. The activity associated with processing and conserving fruits and vegetables involved $88 \%$ entities, while remaining $12 \%$ were involved in juices and beverages production [11]. Considering the specificity and diversity of the processed materials, wastewater from fruit and vegetable industry is difficult to characterize $[12,13]$. The largest amounts of wastewater are generated in the first stage of production [13]. Wastewater arising from washing the fruits and vegetables are usually used once. In larger facilities, water used in the first stage is pre-purified in sieves and disposed into the sewerage after washing all fruit and vegetable lot, and then replaced with new water batch. In opinion of Nawirska (2007), wastewater generated in fruit and vegetable industry facilities are characterized by high amounts of carbohydrates and minerals as well as variable composition depending on the raw material and season $[3,12,14]$. Its composition is also affected by washing and line disinfection processes [15]. Washing introduces solid, colloid, and dissolved contaminants into the wastewater, which is dependent on the type of raw material processed, but also on technological process applied. At the same time, difficult to determine quantities of washing and disinfection agents penetrate to wastewater. Depending on the site of wastewater generation, following stages can be distinguished: raw material washing, purification, peeling, blanching, cooling (post-cooling medium), or filling. Composition and amounts of wastewater also depend on: type, quality, setup and size of a washer, type and origin of raw material $[15,16]$. Wastewater generated during fruit concentrates production is characterized by reaction from 5.8 to 9.4 along with COD value from 1030 to $5630 \mathrm{mgO}_{2} / \mathrm{dm}^{3}$ [17]. In facilities producing diverse assortment, e.g. salads, puree, marinades, the acidity range can be from 4.9 to 7.7 , while COD value from 5260 to $270 \mathrm{mgO}_{2} / \mathrm{dm}^{3}$. These levels depend on production technology and currently processed raw material [17]. Wastewater from fruit and vegetable processing is deficient in nitrogen and its main contaminant is organic substance $[10,15)$. According to literature, the $\mathrm{BOD}_{5}$ value can amount from 500 to $5000 \mathrm{mgO}_{2} / \mathrm{dm}^{3}$, whereas during the production season, it even exceeds $5000 \mathrm{mgO}_{2} / \mathrm{dm}^{3}$ [10, 18-20]. These concentrations are much higher than in household-farm wastewater [10,21, 22], while comparable to those reported by Demirel et al. [23], Puchlik et al. [3] and Neczaj et al. [24] from dairy industry. Seasonal oscillations in quality of wastewater from fruit and vegetable industry became problem for many conventional treatment plants, to which they are disposed [25-32]. 


\section{Materials and methods}

Experiments were carried out in Department of Technology in Engineering and Environmental Protection and certified laboratory of Białystok Waterworks Ltd. in Białystok according to APHA [33]. Samples of raw wastewater were collected according to Polish norm [34] 4 times a month since January till December in 2013-2016 from the facility in north-eastern Poland producing fruit and vegetable juices, processed and frozen products, and vegetable concentrates. Physicochemical analyses included: acidity, $\mathrm{BOD}_{5}$, COD, total nitrogen, total phosphorus, total solid suspension (TSS). Achieved average monthly results from physicochemical determinations of raw wastewater were subjected to statistical analysis using Statistica 13.1 software in order to confirm the linear dependencies for the production season (since June till October) and out of this period (since January till May and since November till December). Pearson correlation at the significance level of $\alpha=0.05$ was applied assuming values from $[-1,1]$ interval. The calculations take into account general measures of the above parameters including arithmetic mean, median, minimum, maximum, and standard deviation.

\section{Results}

Studies upon the composition of raw wastewater in selected fruit and vegetable processing plants were carried out in 2013-2016. Wastewater from facilities producing a wide range of assortment was analyzed. These facilities produce fruit and vegetable juices, processed and frozen products, and vegetable concentrates on a national scale, and the production is performed the whole year. Results from physicochemical determinations of raw wastewater made possible to analyze in details the changes in wastewater quality within 2013-2016. Tables 1-2 present study results for raw wastewater, which were divided into the campaign and out of this period. It was found that intensified production of juices and processed products in summer causes an increase in organic compounds concentrations expressed as $\mathrm{COD}$ and $\mathrm{BOD}_{5}$, as well as increase in the total solid suspension in wastewater. Tables 1 and 2 present significant differences for both periods at intensified juice and processed vegetables production and out of the production campaign, during which frozen and concentrated vegetables dominated. Wastewater from fruit and vegetable industry collected since June till October were characterized by much higher values of COD and $\mathrm{BOD}_{5}$ as compared to that collected since January till May and December till January. The highest average levels of $\mathrm{BOD}_{5}$ and $\mathrm{COD}$ were recorded during the production campaign (Table 1). The $\mathrm{BOD}_{5}$ levels varied from 500 up to $6100 \mathrm{mgO} \cdot \mathrm{dm}^{-3}$, while COD from 1256 to $7732 \mathrm{mgO}_{2} \cdot \mathrm{dm}^{-3}$ during the intensified juice production since June till October. Meanwhile out of the campaign, values of $\mathrm{BOD}_{5}$ were from 535 to $4000 \mathrm{mgO}_{2} \cdot \mathrm{dm}^{-3}$ and COD from 806 to $6436 \mathrm{mgO}_{2} \cdot \mathrm{dm}^{-3}$. Sewage disposed from the fruit and vegetable processing facility were characterized by low concentrations of total nitrogen. The mean content for the production campaign period was $62.1 \mathrm{mgN} \cdot \mathrm{dm}^{-3}$, while for the remaining period 58.9 $\mathrm{mgN} \cdot \mathrm{dm}^{-3}$. Similar statistical distribution of total nitrogen concentrations within the whole study, was observed. Maximum total phosphorus content amounting to $178.4 \mathrm{mgP} \cdot \mathrm{dm}^{-3}$ was observed during the campaign, whereas minimum equal to $7.6 \mathrm{mgP} \cdot \mathrm{dm}^{-3}-$ out of the production campaign. When analyzing the total solid suspensions concentration, a considerable increase was found since June till October $\left(825.4 \mathrm{mg} \cdot \mathrm{dm}^{-3}\right)$. This increase in total solid suspension in summer was associated with production intensification. Enhancing production since June till October also resulted from introduction of fresh fruits and vegetables (strawberry, carrot, beet, apple, cherry, sweet cherry, currant, gooseberry), which in consequence caused the increase in contaminants concentrations in wastewater. Decrease in the contamination levels was recorded in the remaining period, which was 
caused by a stable production of frozen and concentrated vegetables. Acidity of wastewater from fruit and vegetable industry oscillated from 3.7 up to 10.2 during the campaign, while from 3.2 to 9.8 out of that period. Analysis of the total solid suspensions revealed their increase during the production intensification, whereas decrease in winter and spring. A strong linear dependence between total solid suspension vs. values of COD and $\mathrm{BOD}_{5}$ was found (Table 3).

Table 1. Quality of raw wastewater from fruit and vegetable industry during the production campaign in 2013-2016.

\begin{tabular}{|c|c|c|c|c|c|c|}
\hline Parameter & Unit & Average & Median & $\begin{array}{c}\text { Standard } \\
\text { deviation }\end{array}$ & Minimum & Maximum \\
\hline $\mathrm{COD}$ & $\mathrm{mgO}_{2} \cdot \mathrm{dm}^{-3}$ & 2820.0 & 2604.0 & 1254.3 & 1256.0 & 7732.0 \\
\hline $\mathrm{BOD} 5$ & $\mathrm{mgO}_{2} \cdot \mathrm{dm}^{-3}$ & 2361.3 & 2319.0 & 1020.6 & 500.0 & 6100.0 \\
\hline TSS & $\mathrm{mg} \cdot \mathrm{dm}^{-3}$ & 825.4 & 698.6 & 502.0 & 239.0 & 2367.0 \\
\hline Total Phosphorus & $\mathrm{mgP} \cdot \mathrm{dm}^{-3}$ & 17.5 & 12.8 & 26.3 & 7.9 & 178.4 \\
\hline Total Nitrogen & $\mathrm{mgN} \cdot \mathrm{dm}^{-3}$ & 62.1 & 65.3 & 16.8 & 29.0 & 88.3 \\
\hline $\mathrm{pH}$ & - & - & - & - & 3.7 & 10.2 \\
\hline
\end{tabular}

Table 2. Quality of raw wastewater from fruit and vegetable industry out of the production campaign in 2013-2016.

\begin{tabular}{|c|c|c|c|c|c|c|}
\hline Parameter & Unit & Average & Median & $\begin{array}{c}\text { Standard } \\
\text { deviation }\end{array}$ & Minimum & Maximum \\
\hline $\mathrm{COD}$ & $\mathrm{mgO}_{2} \cdot \mathrm{dm}^{-3}$ & 2113.9 & 1819.0 & 1162.6 & 806.0 & 6436.0 \\
\hline $\mathrm{BOD} 5$ & $\mathrm{mgO}_{2} \cdot \mathrm{dm}^{-3}$ & 1660.3 & 1208.0 & 1012.1 & 535.0 & 4000.0 \\
\hline $\mathrm{TSS}$ & $\mathrm{mg} \cdot \mathrm{dm}^{-3}$ & 649.9 & 377.0 & 660.9 & 165.0 & 3268.0 \\
\hline Total Phosphorus & $\mathrm{mgP} \cdot \mathrm{dm}^{-3}$ & 13.6 & 11.6 & 5.0 & 7.6 & 32.9 \\
\hline Total Nitrogen & $\mathrm{mgN} \cdot \mathrm{dm}^{-3}$ & 58.9 & 60.0 & 13.8 & 32.7 & 106.0 \\
\hline $\mathrm{pH}$ & - & - & - & - & 3.2 & 9.8 \\
\hline
\end{tabular}

Table 3. Correlation of variables for raw wastewater from fruit and vegetable industry in 2013-2016.

\begin{tabular}{|c|c|c|c|c|c|}
\hline Variable & COD & BOD5 & TSS & $\begin{array}{c}\text { Total } \\
\text { Phosphorus }\end{array}$ & $\begin{array}{c}\text { Total } \\
\text { Nitrogen }\end{array}$ \\
\hline COD & 1.00 & 0.86 & 0.45 & 0.13 & 0.10 \\
\hline BOD5 & 0.86 & 1.00 & 0.43 & 0.09 & 0.21 \\
\hline TSS & 0.45 & 0.43 & 1.00 & 0.15 & 0.19 \\
\hline $\begin{array}{c}\text { Total } \\
\text { Phosphorus }\end{array}$ & 0.13 & 0.09 & 0.15 & 1.00 & 0.09 \\
\hline $\begin{array}{c}\text { Total } \\
\text { Nitrogen }\end{array}$ & 0.10 & 0.21 & 0.19 & 0.09 & 1.00 \\
\hline
\end{tabular}

\section{Conclusions}

The study results subjected to analyses allow for drawing the following conclusions:

1. In the case of tested parameters, it is evident their remarkable variability due to the type of production process in fruit and vegetable processing plant. It is characterized by the presence of intensified production period, when fruit and vegetable juices are produced, processed products during the campaign, as well as frozen and concentrated vegetables (out of the campaign) along with the 
downtimes of technological lines, when conservation works and washing of devices is performed.

2. Remarkable seasonal oscillations in the concentrations of contaminants disposed with the industrial wastewater into the sewerage. Since June till October, they increased by about $50 \%-60 \%$ as compared to the remaining periods.

3. Organic substance expressed as $\mathrm{COD}$ and $\mathrm{BOD}_{5}$ as well as total soil suspensions were the general contaminants present in wastewater from fruit and vegetable processing facility.

4. Wastewater from fruit and vegetable industry, as compared to the typical sewage from sewerage, was characterized by much higher values of $\mathrm{BOD}_{5}$ and $\mathrm{COD}$, as well as much lower levels of total nitrogen and phosphorus.

5. Calculations revealed that $\mathrm{COD}$ to $\mathrm{BOD}_{5}$ ratio for raw wastewater from analyzed facility was lower than 2 indicating that the sewage is readily bio-degradable.

6. Achieved results from studies upon raw wastewater from the facility producing fruit and vegetable juices, processed products, and frozen and concentrated vegetables, confirm the necessity to carry out the qualitative and quantitative studies of disposed wastewater.

The research has been carried out in the framework of project No. MB/WBiIŚ/13/2015 and financed from the funds for science MNiSW and as well as by courtesy and help of Biatystok Waterworks Ltd.

\section{References}

1. R.M. Kirby, J. Bartram, R. Carr, Food Control 14, 5 (2003)

2. A. Kotowski, B. Kaźmierczak, M. Wdowikowski, Environ. Prot. Eng. 35 (2013)

3. M. Puchlik, J. Struk-Sokołowska, E3S Web Of Conferences (to be published)

4. W. Dąbrowski, M. Puchlik, Annual Set Environment Protection, 12 (2010)

5. K. Ignatowicz, M. Puchlik, Annual Set Environment Protection, 13 (2011)

6. GUS Central Statistical Office, Entities of the national economy registered in the REGON register, declaring their activity according to particular legal forms and PKD200, Quarterly information on entities of the national economy in REGON register declaring the economic activity (2015)

7. GUS Central Statistical Office, Environmental Protection, Information and statistics. Warszawa 2013-2015 (2015)

8. R. Al-Isawi, M. Scholz,Y. Wang, 15th IWA International Conference on Wetland Systems for Water Pollution Control, Conference Proceedings, 1 (2016)

9. J.A. Alvarez., D. De la Varga, A. Pascual, D. V. Oirschot, R. Kilian, P.N. Carvalho, H. Brix, 15th IWA International Conference on Wetland Systems for Water Pollution Control, Conference Proceedings, 1 (2016)

10. M. Soroko, Water, Environment, Rural Areas, 3 (2003)

11. S. Kierczyńska, Yearbooks X, 4 (2008)

12. A. Nawirska, Agro Industry 3 (2007)

13. M. Strzelczyk, A. Steinhoff-Wrześniewska, A. Rajmund Pol. J. Chem. Tech. 12, 4 (2010) 
14. G. Murtaza, A. Ghafoor, M. Qadir, G. Owens, M.A. Aziz, M. H. Zia, Saifullah Pedosphere 20, 1 (2010)

15. M. Puchlik, Journal of Ecological Engineering 17, 1 (2016)

16. A. Nawirska, L. Szymański, Publishing House of Agricultural University in Wroclaw, (2002)

17. D. Kopiec, Communal Review, 2 (2007)

18. B. Koziorowski, Treatment of industrial wastewater (WTN, Warsaw, 1980)

19. F. Meinck, H. Stoof, Kohlschutter, Industrial wastewater (1975)

20. B. Talik, B. Chudzik, IMUZ 20, 3 (2000)

21. M. Puchlik, K. Ignatowicz, W. Dąbrowski, Journal of Ecological Engineering 16, 1 (2015)

22. B. Bartkiewicz, K. Umiejewska, Treatment of industrial wastewater (PWN, 2010)

23. B. Demirel, O. Yenigun, T.T. Onay, Proc. Biochem. 40 (2005)

24. E. Neczaj, M. Kacprzak, T. Kamizela, J. Lach, E. Okoniewska, Desalination, 222 (2008)

25. K. Ignatowicz, J. Piekarski, D. Kozłowski, Annual Set Environment Protection, 17 (2015)

26. P. Kogut, J. Piekarski, K. Ignatowicz, Annual Set Environment Protection, 16 (2014)

27. C.A. Arias, $15^{\text {th }}$ IWA International Conference on Wetland Systems for Water Pollution Control, Conference Proceedings, 1 (2016)

28. R.G. Andries, A.T. de Matos, W. Freitas, $15^{\text {th }}$ IWA International Conference on Wetland Systems for Water Pollution Control, Conference Proceedings, 1 (2016)

29. J.S. Bays, $15^{\text {th }}$ IWA International Conference on Wetland Systems for Water Pollution Control, Conference Proceedings, 1 (2016)

30. K. Haarstad, J. Bavor,. $15^{\text {th }}$ IWA International Conference on Wetland Systems for Water Pollution Control, Conference Proceedings, 1 (2016)

31. P. Haase, A. Carter, E. Corwin, P. Myer, $15^{\text {th }}$ IWA International Conference on Wetland Systems for Water Pollution Control, Conference Proceedings, 1 (2016)

32. E. Jiao, Ch. Gao, Q. Zhang, Y. Tian, , $15^{\text {th }}$ IWA International Conference on Wetland Systems for Water Pollution Control, Conference Proceedings, 1 (2016)

33. E.W. Rice, R.B. Baird, A.D. Eaton, L.S. Clesceri, Standard Methods for the Examination of Water and Wastewater, American Public Health Association (APHA), American Water Works Association (AWWA), Water Environment Federation (WEF), 22nd Edition (2012)

34. PN-ISO 5667-10:1997, Water quality - Sampling - Guidelines for the sampling of wastewater in Poland 